\title{
Effect of milk type and processing on iodine concentration of organic and conventional winter milk at retail: implications for nutrition
}

Article

Accepted Version

Payling, L. M., Juniper, D. T., Drake, C., Rymer, C. and Givens, D. I. (2015) Effect of milk type and processing on iodine concentration of organic and conventional winter milk at retail: implications for nutrition. Food Chemistry, 178. pp. 327-330. ISSN 0308-8146 doi:

https://doi.org/10.1016/j.foodchem.2015.01.091 Available at https://centaur.reading.ac.uk/39199/

It is advisable to refer to the publisher's version if you intend to cite from the work. See Guidance on citing.

Published version at: http://www.sciencedirect.com/science/article/pii/S0308814615001053

To link to this article DOI: http://dx.doi.org/10.1016/j.foodchem.2015.01.091

Publisher: Elsevier

All outputs in CentAUR are protected by Intellectual Property Rights law, including copyright law. Copyright and IPR is retained by the creators or other copyright holders. Terms and conditions for use of this material are defined in the End User Agreement. 


\section{www.reading.ac.uk/centaur}

\section{CentAUR}

Central Archive at the University of Reading

Reading's research outputs online 
2 Effect of milk type and processing on iodine concentration of organic and conventional winter milk at retail: implications for nutrition

4

$5 \quad$ Laura M. Payling, Darren T. Juniper, Chris Drake, Caroline Rymer and D. Ian Givens ${ }^{1}$

6 Food Production and Quality Division, Faculty of Life Sciences, University of Reading,

7 Reading RG6 6AR, UK

8

9 Short title: Iodine in organic and normal winter milk

11 Keywords: Iodine: Milk: Organic: UHT, Fat class

\footnotetext{
${ }^{1}$ Corresponding author, Tel: +44 118378 8491; email: d.i.givens@reading.ac.uk
} 
Abstract

13

Milk is the largest source of iodine in UK diets and an earlier study showed that organic summer milk had significantly lower iodine concentration than conventional milk. There are no comparable studies with winter milk or the effect of milk fat class or heat processing method. Two retail studies with winter milk are reported. Study 1 showed no effect of fat class but organic milk was $32.2 \%$ lower in iodine than conventional milk (404 vs. $595 \mu \mathrm{g} / \mathrm{L}$; $P<0.001)$. Study 2 found no difference between conventional and Channel Island milk but organic milk contained $35.5 \%$ less iodine than conventional milk (474 vs. $306 \mu \mathrm{g} / \mathrm{L}$; $P<0.001)$. UHT and branded organic milk also had lower iodine concentrations than conventional milk $(331 \mu \mathrm{g} / \mathrm{L} ; P<0.001$ and $268 \mu \mathrm{g} / \mathrm{L}: P<0.0001$ respectively). The results indicate that replacement of conventional milk by organic or UHT milk will increase the risk of sub-optimal iodine status especially for pregnant/lactating women.

\section{Keywords: Iodine: Milk: Organic: UHT, Fat class}

\section{Introduction}

Iodine is a key component of the hormones produced by the thyroid gland which are particularly important during pregnancy for foetal brain development (Zimmermann, 2009). The UK Reference Nutrient Intakes (RNI) for iodine are 130 and $140 \mu \mathrm{g} / \mathrm{d}$ for children aged 11-14 years and adults respectively with no increase during pregnancy or lactation (Department of Health, 1991), compared with $150 \mu \mathrm{g}$ iodine/d for adults by the US Institute of Medicine (IOM) and the World Health Organisation (WHO). IOM also proposes an increase of 47 and 93\% during pregnancy and lactation respectively whereas WHO advises an 
increase of $67 \%$ for both (Zimmermann, 2009). In many countries provision of iodised salt has reduced the incidences of iodine deficiency, but in countries such as the UK widespread interventions have not been enforced (Phillips, 1997). This has led to a sustained level of mild iodine deficiency in many populations, notably about $44 \%$ of children and adults in Europe (Zimmermann \& Andersson, 2011).

For some time the UK population has been assumed to be of adequate iodine status (Wenlock, Buss, Moxon \& Bunton, 1982). However, a study in UK schoolgirls recorded mild iodine deficiency in $51 \%$ of the participants based on urinary iodine concentrations (Vanderpump et al., 2011) and the recently published UK National Diet and Nutrition Survey (Bates et al., 2014) reports that on average, young females aged 11 to 18 years consume only $81 \%$ of the RNI for iodine and that $22 \%$ of young females have iodine intakes below the Lower RNI (70 $\mu \mathrm{g}$ iodine/d). In addition, mild-to-moderate iodine deficiency has been demonstrated in a large UK cohort of pregnant women (Bath, Walter, Taylor, Wright \& Rayman, 2014) together with evidence of an association between low maternal iodine status in early pregnancy and poorer verbal IQ, reading accuracy and reading comprehension in the children (Bath, Rayman, Steer, Goulding \& Emmett, 2013).

In the UK, milk and dairy foods are the largest dietary source of iodine providing 40 and 39 $\%$ of the daily intake of iodine for 11-18 year old males and females respectively (Bates et al., 2014). Both genders obtain the majority ( 43\%) of the dairy food contribution from semiskimmed milk (Bates et al., 2014). Survey studies on milk iodine concentrations carried out in the last 14 years (Ministry of Agriculture, Fisheries and Food, 2000; Food Standards Agency, 2008) are not suggestive of any overall reduction in UK milk iodine concentration but they do show that iodine concentration is highly variable and that milk produced in the 
summer has on average, a 50\% lower iodine concentration than winter milk. Moreover, the studies of The Food Standards Agency (2008) and Bath, Button \& Rayman (2012) both showed that summer milk from organic dairy systems had significantly lower $(\sim-40 \%)$ iodine concentrations than from conventional systems. These findings clearly have implications for human iodine intake and status but there is little evidence on conventional vs. organic milk produced in winter, the effect of milk fat class (whole, semi-skimmed, skimmed) or the effect of milk processing method. Accordingly, two UK retail studies were therefore undertaken with the objectives of comparing the iodine content of 1) organic and conventional winter milk, 2) whole, semi-skimmed and skimmed milk and 3) pasteurised and ultra-high temperature (UHT) treated milk.

\section{Materials and methods}

\subsection{Milk samples}

In Study 1, the intention was to purchase two samples of pasteurised conventionally and organically produced whole (full fat), semi-skimmed and skimmed milk from two leading supermarkets in the Reading area in late January 2014. However, Supermarket 1 did not stock organic skimmed milk when visited, leading to a total of 22 samples. In Study 2, five different milk product types (conventional semi-skimmed, organic semi-skimmed, branded organic semi-skimmed, UHT semi-skimmed and conventional whole milk from Channel Island breeds of cow) were purchased from four leading supermarkets in the Reading area in each of three consecutive weeks, beginning in the first week of February 2014 giving a total of 60 samples. Except for the UHT milk, all other types were pasteurised. In both studies all 
milks were supermarket own brand except for the branded organic milk in Study 2. All milk samples were stored at $-20^{\circ} \mathrm{C}$ pending analysis.

\subsection{Sample analysis}

Milk samples were allowed to defrost overnight and thoroughly mixed by vortexing before analysis. Samples from Study 1 had fat, protein and lactose concentrations measured by methods of International Organisation for Standardisation (2008), Davis \& Macdonald (1953) and Sanchez-Manzanarea, Fernandez-Villacaas, Marin-Iniesta \& Laencina (1993) respectively. Iodine concentration was measured in all samples by alkali extraction followed by inductively coupled plasma mass spectrometry (ICP-MS) based on the method of Fecher, Goldman \& Nagengast (1998). In brief $100 \mu \mathrm{l}$ of milk were diluted to $10 \mathrm{ml}$ with $2 \%$ tetramethyl ammonium hydroxide in ultra-pure water and containing $5 \mu \mathrm{g} / \mathrm{L}$ of rhodium as an internal standard. Analysis was then undertaken by ICP-MS (iCAP Q, Thermo Scientific Scientific Inc. Waltham, MA, USA). Certified standard solutions (Romil Ltd, Cambridge, UK) based on ammonium iodide were treated as for milk samples leading to final concentrations of $0,2,4,6,8$ and $10 \mu \mathrm{g} / \mathrm{L}$ iodine.

\subsection{Statistical analysis}

The effect of milk product type (conventional production, Channel Island, organic production, UHT, branded organic), milk fat class (whole, semi-skimmed, skimmed) and supermarket of origin were determined as appropriate to each study, by fixed effect analysis of variance using a general linear model (Mintab version 16; Minitab Inc., State College, PA, 
USA). Tukey's pairwise multiple comparison test was then used to identify which treatments were significantly different from each other when the significance was $\mathrm{P}<0.05$.

\section{Results}

\subsection{Study 1}

(1)

There was no significant effect of conventional vs. organic production system on fat, protein or lactose contents of the milks. Fat content was significantly $(P<0.001)$ affected by milk fat class with mean values of $3.55,1.42$ and $0.01 \mathrm{~g} / 100 \mathrm{~g}$ for whole, semi-skimmed and skimmed milk respectively. The iodine concentrations of the milks are shown in Table1. There was no effect of milk fat class and overall, no fat class x production system interaction although such an interaction was seen for milk from Supermarket 2 which was related to some small fat class effects $(P<0.05)$ in conventional but not organic milk. Overall, there was a significant $(P<0.001)$ effect of production system with organic milk having consistently lower iodine concentrations than conventional. Mean iodine concentration in organic milk was $32.2 \%$ lower than of conventional.

\subsection{Study 2}

The iodine concentrations of the milk types are shown in Table 2. Overall, milk iodine concentration was not affected by supermarket but was significantly $(P<0.001)$ influenced by milk production system with organic and branded organic milk having lower iodine concentrations than conventional. Branded organic milk had the lowest mean iodine concentration and this had a tendency to be lower than own-brand organic $(P<0.059)$. 
Overall, the iodine concentration of organic (including branded organic) milk was $35.5 \%$ lower than conventional. A production system $x$ supermarket interaction $(P<0.05)$ was seen due to Supermarket 2 having unusually high iodine concentrations in its milk labelled as organic. If data from this supermarket are excluded the iodine concentration of organic (including branded organic) milk was $43.9 \%$ lower than conventional. Interestingly, conventionally produced UHT milk had a lower $(P<0.05)$ iodine concentration than conventional pasteurised milk with a mean value not significantly different to organic milk. Iodine in Channel Island milk was not significantly different to conventional milk.

\section{Discussion}

To our knowledge, this is the first balanced comparison of the iodine concentration of conventional and organic UK retail milk produced in the winter. The Food Standards Agency (2008) reported a study on milk purchased between January and March 2007 but that study involved only whole milk and was not balanced, involving 62 conventional and 14 organic milks. Despite this, the mean values of the current study agree quite well with those of the Food Standards Agency (2008) which reported values of 441 and $391 \mu \mathrm{g} / \mathrm{L}$ for conventional and organic milk respectively, though no statistical comparison was reported. The key finding of the current study that winter produced organic milk has a significantly lower iodine concentration (-32.2, -35.5\%; Study1, Study 2) than winter produced conventional milk, agrees with an earlier UK study (Bath et al., 2012) and two in Scandinavia (Rasmussen, Larsen \& Ovesen, 2000; Dahl, Opsahl, Meltzer \& Julshamn, 2003) comparing conventional with organic summer milk. However both the conventional and organic milk in the present study had higher iodine concentrations than the respective values in the UK summer milk 
winter has higher iodine concentrations than that produced in summer (Flachowsky, Franke, Meyer, Leiterer, \& Schöne, 2014). This is because iodine intake by the dairy cow is a key determinant of milk iodine concentration and housed cows in winter will receive more iodine supplementation via concentrate feed than cows grazing outdoors in summer (Flachowsky et al., 2014). Indeed since diets for dairy cows on an organic system are mandated to rely more heavily on forages than in conventional systems (European Union, 2008), this is also likely to be the main reason for organic milk having lower iodine concentrations although additional reasons have been proposed (Flachowsky et al., 2014). The finding that branded organic milk had a tendency $(\mathrm{P}<0.059)$ to have a lower iodine content than supermarket own brand organic milk agrees with the findings of Bath et al. (2012) who showed that branded organic summer milk (mean $118.3 \mu \mathrm{g} / \mathrm{L})$ was significantly $(\mathrm{P}<0.001)$ lower than supermarket own-brand organic (mean $159.8 \mu \mathrm{g} / \mathrm{L}$ ). The reasons for this are not known but may relate to less iodine supplementation to the dairy cows and perhaps less use of iodine containing animal health products (e.g. teat dips) than for supermarket own-brand organic milk.

One report from a large Spanish milk study in 2008 (Soriguer et al., 2011) showed that the iodine concentration was greater $(\mathrm{P}<0.001)$ in skimmed milk (mean $273 \mu \mathrm{g} / \mathrm{L} ; \mathrm{n}=107)$ than in semi-skimmed milk (mean $254 \mu \mathrm{g} / \mathrm{L} ; \mathrm{n}=121$ ) or whole milk (mean $251 \mu \mathrm{g} / \mathrm{L} ; \mathrm{n}=134$ ). Whilst the logic for this might relate to iodine dilution as fat content is increased, no such effect was seen in the present study and as Soriguer et al. (2011) indicate, the variation due to fat content is very small compared with the large variation in iodine concentration seen in most studies. There are also few reports on the effect of milk processing on iodine concentration. Flachowsky et al. (2014) summarised the results of two Iranian studies (Norouzian, Valizadeh. Azizi, Hedayati, Naserian, \& Eftekhari Shahroodi, 2009; Norouzian, 2011) and concluded that between 18 and 53\% of iodine in raw milk was lost during pasteurisation 
$(P<0.01)$ with the loss being inversely related to the iodine content of the raw milk. It was proposed that the losses were due to the sublimation characteristic of iodine as $>90 \%$ of milk iodine is in the inorganic form (Flachowsky et al., 2014) although how this occurs in an essentially sealed system is unclear. In the present study all the milk was pasteurised (typically $72^{\circ} \mathrm{C}$ for 15 seconds) except for the UHT milk which would have been processed typically at $140^{\circ} \mathrm{C}$ for 3 to 5 seconds. It seems possible therefore that the significantly lower iodine concentration in the UHT milk compared with conventional may be a result of the milk market (Dairy Co, 2014), in many neighbouring EU Member States UHT milk represents most of the milk consumed with for example France, The Netherlands and Germany where UHT accounts for about 90, 80 and 65\% respectively (Department for Environment, Food and Rural Affairs, 2007). The impact of UHT processing should therefore be explored in greater depth.

For adults the UK the RNI for iodine is $140 \mu \mathrm{g} / \mathrm{d}$ with no increase during pregnancy or lactation (Department of Health, 1991) despite evidence that potassium iodide supplementation (providing $153 \mu \mathrm{g} \mathrm{I} / \mathrm{d}$ ) during lactation significantly increases breast milk iodine concentration and iodine status of premature infants (Gónzalez-Iglesias et al., 2012). Assuming the mean intake of milk by UK women (aged 19-64 years) is $125 \mathrm{ml} / \mathrm{d}$ (Bates et al., 2014) the results in Table 2 would predict iodine intakes from milk of 59 and $43 \mu \mathrm{g} / \mathrm{d}$ from conventional and organic/UHT/branded organic winter milk respectively, representing 42 and $31 \%$ of the RNI. Milk consumption in the UK has declined by about $23 \%$ over the last 20 years (Department for Environment, Food and Rural Affairs, 2013) with a greater reduction by young women than men, and whilst this is likely to be a major contributory factor to the low iodine status seen in pregnant women (Bath et al., 2014), a key conclusion 
of the present study is that choosing to consume winter organic or UHT milk will increase the risk of sub-optimal iodine status, particularly during pregnancy and lactation, in agreement with the conclusions of Bath et al. (2012) for summer milk.

The present study has weaknesses. The sample number was not large and fewer samples than planned were available for Study 1. Nevertheless, the findings regarding the relative iodine concentrations in winter milk from differing production systems and processing methods are important issues in understanding the effects of diet on iodine status. The present study was also limited to supermarkets in the Reading area although the retail study of Bath et al. (2012) found no significant effect of area of milk purchase, arguing that retail milk is relatively homogenous as result of collections from wide geographical locations being taken for central processing and distribution to supermarkets over a wide area. There were however supermarket $\mathrm{x}$ production system interactions seen in both current studies which were related to inconsistencies between supermarkets in the effect of production system on iodine content. The reasons for this are unknown but possibly point to differences between supermarkets' milk producers or to labelling errors.

\section{Conclusions}

Both studies showed that organic winter milk was significantly lower $(\sim 34 \%)$ in iodine concentration than conventional milk in agreement with an earlier study with summer milk. No effect of fat class was seen but UHT and branded organic milk had lower iodine concentrations than conventional milk. The results for winter milk agree with conclusions in an earlier study with summer milk that replacement of conventional milk by organic milk will increase the risk of sub-optimal iodine status especially for young women in periods of 
237 warranted.

238

239 Acknowledgements

240

241 We thank Dr Yan Gao for her expert contribution to the milk analysis and the University of

242 Reading for funding the studies. All authors contributed to the writing and reviewing of the

243 paper and approved the final document. None of the authors had any conflict of interest to 244 declare. 
Bates, B., Lennox, A., Prentice, A., Bates, C., Page, P., Nicholson, S., \& Swan, G. (2014). National Diet and Nutrition Survey, Results from Years 1-4 (combined) of the Rolling Programme (2008/2009-2011/12). A survey carried out on behalf of Public Health England and the Food Standards Agency.

Bath, S. C., Button, S., \& Rayman, M. P. (2012). Iodine concentration of organic and conventional milk: implications for iodine intake. British Journal of Nutrition, 107, 935-940.

Bath, S. C., Rayman, M. P., Steer, C. D., Golding, J., \& Emmett, P. (2013). Effect of inadequate iodine status in UK pregnant women on cognitive outcomes in their children: results from the Avon Longitudinal Study of Parents and Children (ALSPAC). The Lancet, 382 (9889), pp. 331-337.

Bath, S. C., Walter, A., Taylor, A., Wright, J., \& Rayman, M. P. (2014). Iodine deficiency in pregnant women living in the South East of the UK: the influence of diet and nutritional supplements on iodine status. British Journal of Nutrition, 111, 1622 - 1631,

Dahl, L., Opsahl, J. A., Meltzer, H. M., \& Julshamn, K. (2003). Iodine concentration in Norwegian milk and dairy products. British Journal of Nutrition, 90, 679-685.

Dairy Co (2014). Market Information. http://www.dairyco.org.uk/market-information/dairysales-consumption/liquid-milk-market/liquid-milk-market/ Accessed 01.05.14.

265 Davis, J. G., \& Macdonald, F. J. (1953). Total protein content from acidity and pH 266 determination. In Richmond's Dairy Chemistry Fifth Edition. (p 362). London: Charles Griffin \& Co. Ltd. 
Department for Environment, Food and Rural Affairs (2013). Family Food 2012, Report

Tables and Charts. https://www.gov.uk/government/collections/family-food-statistics (accessed 13 May 2014).

271 Department for Environment, Food and Rural Affairs (DEFRA) (2007). The Potential for 272 GB-European Trade in Liquid Milk. (71 pp). London: DEFRA,

273 Department of Health (1991). Report of the panel on dietary reference values of the 274 Committee on Medical Aspects of Food Policy (COMA). In Dietary Reference Values for 275 Food Energy and Nutrients for the United Kingdom. London: The Stationery Office.

276 European Union (2008). Commission Regulation (EC) no. 889/2008 of 5 September 2008 277 laying down detailed rules for the implementation of Council Regulation (EC) no. 834/2007 on organic production and labelling of organic products with regard to organic production, labelling and control. Official Journal of the European Union 51, L250.

280 Fecher, P. A., Goldmann, I., \& Nagengast, A. (1998). Determination of iodine in food 281 samples by inductively coupled plasma mass spectrometry after alkaline extraction. Journal 282 of Analytical Atomic Spectrometry, 13, 977-982.

283 Flachowsky, G., Franke, K., Meyer, U., Leiterer, M., \& Schöne, F. (2014). Influencing 284 factors on iodine content of cow milk. European Journal of Nutrition, 53, 351-365. 02/08. London: Food Standards Agency. 
Ibáñez-Fernández, A., Solís, G., Sanz-Medel, A., \& Fernández-Sánchez, M.L. (2012). Efficiency of iodine supplementation, as potassium iodide, during lactation: A study in neonates and their mothers. Food Chemistry, 133, 859-865.

International Organisation for Standardisation (2008). Milk: Determination of fat content. ISO 2446:2008. Geneva: International Organisation for Standardisation. http://www.iso.org/iso/home/store/catalogue_tc/catalogue_detail.htm?csnumber=51019 Accessed 02.02.14.

Ministry of Agriculture, Fisheries and Food (2000). Iodine in Milk, Food Surveillance Information Sheet 198. London: MAFF Joint Food Safety and Standards Group.

Norouzian, M. A. (2011). Iodine in raw and pasteurized milk of dairy cows fed different amounts of potassium iodide. Biological Trace Element Research, 139, 160-167.

Norouzian, M. A., Valizadeh, R., Aziz,i F., Hedayati, M., Naserian. A. A., \& Eftekhari Shahroodi, F. (2009). The effect of feeding different levels of potassium iodide on performance, T-3 and T-4 concentrations and iodine excretion in Holstein dairy cows. Journal of Animal and Veterinary Advances, 8, 111-114.

Phillips, D. I. (1997). Iodine, milk, and the elimination of endemic goitre in Britain: the story of an accidental public health triumph. Journal of Epidemiology and Community Health, 51, 391-393.

Rasmussen, L. B., Larsen, E. H., \& Ovesen, L. (2000). Iodine content in drinking water and other beverages in Denmark. European Journal of Clinical Nutrition, 54, 57-60.

Sanchez-Manzanarea, J. A., Fernandez-Villacaas, M. R., Marin-Iniesta, F., \& Laencina, J. (1993). Determination of lactose by an enzymatic method. Food Chemistry, 46, 425-427. 
310 Soriguer, F., Gutierrez-Repiso, C., Gonzalez-Romero, S., Olveira, G., Garriga, M. J., 311 Velasco, I., Santiago, P., de Escobar, G., \& Garcia-Fuentes, E. (2011). Iodine concentration 312 in cow's milk and its relation with urinary iodine concentrations in the population. Clinical 313 Nutrition, 30, 44-48.

314 Vanderpump, M. P. J., Lazarus, J. H., Smyth, P. P., Laurberg, P., Holder, R. L., Boelaert, K., 315 \& Franklyn, J. A. (2011). Iodine status of UK schoolgirls: a cross-sectional survey. The $316 \quad$ Lancet, 377 (9782), pp.2007-2012.

317 Wenlock, R. W., Buss, D. H., Moxon, R. E., \& Bunton, N. G. (1982). Trace nutrients. 4. 318 Iodine in British food. British Journal of Nutrition, 47, 381-390.

319 Zimmermann, M. B. (2009). Iodine deficiency. Endocrine Reviews, 30, 376-408.

320 Zimmermann. M. B., \& Andersson, M. (2011). Prevalence of iodine deficiency in Europe in 321 2010. Annales d'Endocrinologie, 72, 164-166.

322 
Table 1. Study 1: Least square mean $( \pm$ SE) iodine concentrations of retail milk as influenced by milk fat class (FC), production system (conventional vs. organic; PS) and supermarket (SM)

\begin{tabular}{|c|c|c|c|c|c|c|c|c|c|c|c|}
\hline \multirow[b]{3}{*}{$\begin{array}{l}\text { Super- } \\
\text { market }\end{array}$} & \multicolumn{6}{|c|}{ Mean iodine concentration $(\mu \mathrm{g} / \mathrm{L})$} & \multirow[b]{3}{*}{ SED } & & & & \\
\hline & \multicolumn{3}{|c|}{ Conventional } & \multicolumn{3}{|c|}{ Organic } & & \multicolumn{4}{|c|}{ P-value for } \\
\hline & $\begin{array}{c}\text { Whole } \\
n=4\end{array}$ & $\begin{array}{c}\text { Semi- } \\
\text { skimmed } \\
n=4\end{array}$ & $\begin{array}{l}\text { Skimmed } \\
n=4\end{array}$ & $\begin{array}{c}\text { Whole } \\
n=4\end{array}$ & $\begin{array}{c}\text { Semi- } \\
\text { skimmed } \\
n=4\end{array}$ & $\begin{array}{c}\text { Skimmed } \\
n=2\end{array}$ & & $\mathrm{FC}$ & PS & $\begin{array}{c}\text { FC x } \\
\text { PS }\end{array}$ & $\begin{array}{c}\text { SM x } \\
\text { PS }\end{array}$ \\
\hline 1 & $486.0 \pm 7.0$ & $560.0 \pm 20.0$ & $502.5 \pm 3.5$ & $482.5 \pm 7.0$ & $454.0 \pm 8.0$ & nd & nd & NS & NS & nd & - \\
\hline 2 & $669.5 \pm 3.5^{\mathrm{ab}}$ & $585.5 \pm 21.5^{\mathrm{b}}$ & $768.5 \pm 24.5^{\mathrm{a}}$ & $316.0 \pm 21.0^{\mathrm{c}}$ & $419.0 \pm 41.0^{\mathrm{c}}$ & $325.5 \pm 12.5^{\mathrm{c}}$ & 33.43 & NS & $<0.001$ & 0.003 & - \\
\hline Overall & $577.8 \pm 53.1^{\mathrm{a}}$ & $572.8 \pm 14.1^{\mathrm{a}}$ & $635.5 \pm 77.4^{\mathrm{a}}$ & $399.2 \pm 48.9^{\mathrm{b}}$ & $436.5 \pm 19.8^{\mathrm{b}}$ & $325.5 \pm 12.5^{\mathrm{b}}$ & 40.67 & NS & $<0.001$ & NS & $<0.001$ \\
\hline
\end{tabular}

${ }^{a, b}$ Means within a row with no superscripts or those with a common superscript are not significantly different $(P>0.05)$; NS, not significant $(P>0.05)$; nd, no or insufficient data due to missing samples; SED, standard error of the difference 
Table 2. Study 2: Least square mean $( \pm \mathrm{SE})$ iodine concentrations of retail milk as influenced by type $(\mathrm{T})$ and supermarket $(\mathrm{SM})$.

\begin{tabular}{|c|c|c|c|c|c|c|c|c|c|}
\hline \multirow[b]{2}{*}{ Supermarket } & \multicolumn{5}{|c|}{ Mean iodine concentration $(\mu \mathrm{g} / \mathrm{L})$} & \multirow[b]{2}{*}{ SED } & \multicolumn{3}{|c|}{$P$-value for } \\
\hline & $\begin{array}{c}\text { Conventional } \\
n=12 \\
\end{array}$ & $\begin{array}{c}\text { Channel } \\
\text { Island } \\
n=12\end{array}$ & $\begin{array}{c}\text { Organic } \\
n=12\end{array}$ & $\begin{array}{l}\text { UHT } \\
n=12 \\
\end{array}$ & $\begin{array}{c}\text { Branded } \\
\text { organic } \\
n=12\end{array}$ & & $\mathrm{~T}$ & SM & $\mathrm{T} \times \mathrm{SM}$ \\
\hline 1 & $433.9 \pm 27.8^{\mathrm{ab}}$ & $436.8 \pm 59.9^{\mathrm{a}}$ & $327.5 \pm 15.1^{\mathrm{ab}}$ & $336.9 \pm 6.85^{\mathrm{ab}}$ & $274.5 \pm 36.6^{b}$ & 48.86 & 0.029 & - & - \\
\hline 2 & $411.1 \pm 62.8$ & $482.1 \pm 17.4$ & $478.7 \pm 74.0$ & $280.7 \pm 33.8$ & $301.5 \pm 43.3$ & 71.38 & 0.046 & - & - \\
\hline 3 & $490.9 \pm 23.6^{\mathrm{a}}$ & $445.3 \pm 56.9^{\mathrm{a}}$ & $279.4 \pm 15.5^{\mathrm{b}}$ & $341.6 \pm 33.6^{\mathrm{ab}}$ & $245.8 \pm 11.9^{\mathrm{b}}$ & 47.17 & 0.002 & - & - \\
\hline 4 & $559.7 \pm 39.2^{\mathrm{a}}$ & $398.8 \pm 35.5^{\mathrm{b}}$ & $287.8 \pm 57.2^{\mathrm{b}}$ & $366.4 \pm 14.2^{\mathrm{b}}$ & $249.2 \pm 28.2^{\mathrm{b}}$ & 48.53 & $<0.001$ & - & - \\
\hline Overall & $473.9 \pm 24.9^{\mathrm{a}}$ & $440.8 \pm 21.5^{\mathrm{a}}$ & $343.4 \pm 30.3^{\mathrm{b}}$ & $331.4 \pm 14.3^{\mathrm{b}}$ & $267.7 \pm 15.3^{\mathrm{b}}$ & 27.10 & $<0.001$ & NS & 0.013 \\
\hline
\end{tabular}

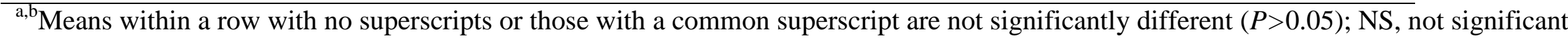
$(P>0.05)$; SED, standard error of the difference 